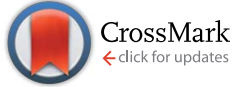

Cite this: RSC Adv., 2017, 7, 482

Received 21st October 2016 Accepted 18th November 2016

DOI: 10.1039/c6ra25606f

www.rsc.org/advances

\section{Novel efficient hole-transporting materials based on a 1,1'-bi-2-naphthol core for perovskite solar cells $\dagger$}

\author{
Wenhua Qiao, Yu Chen, ${ }^{\star}$ Fusheng Li, Xueping Zong, Zhe Sun, Mao Liang \\ and Song Xue*
}

New star-shaped and efficient hole-transporting materials based on a 1,1'-bi-2-naphthol central core for perovskite solar cells are developed via facile synthesis. The 1,1'-bi-2-naphthol is first applied into the field of perovskite solar cells. The 2,7-carbazole-bis(4-methoxy-phenyl)-amine and 3,6-carbazole-bis(4methoxy-phenyl)-amine are used as end groups. A reference compound based on a 3,3'-biphenyl core is prepared as well. The new materials have suitable highest occupied molecular orbital levels to match well with the valence band of $\mathrm{CH}_{3} \mathrm{NH}_{3} \mathrm{Pbl}_{3}$, and they all exhibit a glass transition temperature higher than $160{ }^{\circ} \mathrm{C}$. A device fabricated by hole-transporting materials based on 1,1'-bi-2-naphthol and 2,7carbazole-bis(4-methoxy-phenyl)-amine in conjunction with a carbon counter electrode achieves the highest power conversion efficiency of $8.38 \%$ under the illumination of $100 \mathrm{~mW} \mathrm{~cm}$, which is comparable to that fabricated by commercial spiro-OMeTAD (8.73\%). Dark current, IPCE and IMVS measurements are also discussed. The introduction of 2,7-carbazole-bis(4-methoxy-phenyl)-amine onto the 1,1'-bi-2-naphthol central core tends to enhance $J_{s c}$ of a device, and 3,6-carbazole-bis(4-methoxyphenyl)-amine improves $V_{\text {oc }}$. This work provides a new series of hole-transporting materials to fabricate economic and efficient perovskite solar cells.

\section{Introduction}

Hybrid organic-inorganic perovskite solar cell (PSC) systems have achieved high efficiency up to $20 \% .^{1-5}$ Researchers have been intrigued to explore more possibilities for finding new efficient materials and better understanding interfacial mechanisms. ${ }^{6-10}$ The solid-state hole-transporting materials (HTMs) have been introduced into PSC construction, effectively enhancing the power conversion efficiency (PCE). The state-of-the-art HTM is an organic small molecule based on the spirobifluorene core, ${ }^{\mathbf{1 1}, 12} \quad 2,2^{\prime}, 7,7^{\prime}$-tetrakis-( $N, N$-di- $p$-methoxyphenylamine)-9,9'-spirobifluorene (spiro-OMeTAD). Alternative comparable organic small-molecule HTMs also have been developed for fabricating PSC, ${ }^{\mathbf{1 3}-16}$ due to facial synthesis, low cost and easy to structural modification. The advantage of organic small-molecule HTMs is the property of HTM solution can realize good infiltration into perovskite layer and flexible tuning energy level to match the energy band of organolead halide perovskite and counter electrode. ${ }^{17,18}$ The reported

Tianjin Key Laboratory of Organic Solar Cells and Photochemical Conversion, School of Chemistry \& Chemical Engineering, Tianjin University of Technology, Tianjin 300384, P. R. China. E-mail: cy26tj@icloud.com; xuesong@ustc.edu.cn; Fax: +8622-60214252

$\uparrow$ Electronic supplementary information (ESI) available. See DOI: $10.1039 / \mathrm{c} 6 \mathrm{ra} 25606 \mathrm{f}$ structure of organic small-molecule HTMs for PSC mainly includes linear and star shapes. ${ }^{19-22}$ The commonly used donor groups of organic small-molecule HTMs are derivatives of diphenylamine and triphenylamine, and the newly emerged carbazole-diphenylamines facilitating the HTM with fast charge-transport property.

Several new star-shaped HTMs based on bridged/spiro central core were found to be similarly efficient as spiroOMeTAD. The structure of central core has an impact on the thermal stability of the star-shaped HTM and the solid state of spin-coated HTM film. ${ }^{23,24}$ The commercial spiro-OMeTAD shows a glass transition temperature $\left(T_{\mathrm{g}}\right)$ of $125{ }^{\circ} \mathrm{C}^{25}$ According to reports, a HTM based on a swivel-cruciform $3,3^{\prime}$-bithiophene core in PSC showed an amorphous state and a comparable PCE of $11.0 \%\left(T_{\mathrm{g}}=65{ }^{\circ} \mathrm{C}\right)$ to that derived from spiro-OMeTAD (11.4\%); ${ }^{26}$ a HTM based on a spiro-bipropylenedioxythiophene core tends to crystallize in the solid state, and its photovoltaic performance in PSC (the highest PCE is $13.44 \%, T_{\mathrm{g}}=175{ }^{\circ} \mathrm{C}$ ) was as good as device obtained using spiro-OMeTAD (12.16\%) under the same conditions; ${ }^{27}$ a HTM based on a [2,2]paracyclophane core in PSC yielded a PCE of $17.6 \%\left(T_{\mathrm{g}}=148.5{ }^{\circ} \mathrm{C}\right)$, and the spiro-OMeTAD HTM displayed a $15.4 \%$ in the same situation. ${ }^{28}$ The bridged/spiro core structures of HTM provide a three-dimensional (3D) skeleton, and it is reported the 3D structure of the star-shaped HTM favors the property of charge transport. ${ }^{29-31}$ These findings offer 
inspiration to the development of the bridged/spiro core based HTMs that used for constructing economical and highly efficient PSCs.

Recently, we have synthesized star-shaped HTMs based on 1,1'-bi-2-naphthol (BINOL) core, and it displays a good performance in PSC. Note that, the BINOL-based HTMs show greater advantage over our previously reported HTMs. ${ }^{32,33}$ To our best knowledge, it is the first time for BINOL compounds to be reported in PSC field. BINOL is a typical C2-symmetric aromatic compounds, ${ }^{34,35}$ and it is often used as a ligand for transitionmetal catalyzed asymmetric synthesis, ${ }^{36-40}$ a donor group for charge-transfer complex applied in molecular recognition, ${ }^{\mathbf{4 1 - 4 3}}$ and a structural skeleton for fluorescent chemical sensors for enantioselective fluorescent recognition. ${ }^{\mathbf{4 4 , 4 5}}$ BINOL is a commercial and low-cost compound, and its C2-symmetric feature is good for developing star-shaped HTM with 3D structure. In this work, two HTMs based on a BINOL core and carbazole-diphenylamine arms were studied. The hydroxyl groups of the BINOL were replaced by methoxyl group via etherification reaction. ${ }^{43}$

In this paper, we report the synthesis and characterization of two new HTMs based on a BINOL central core, 9,9'-(2,2'-dimethoxy-1,1' binaphthyl-6,6'-diyl)bis $\left(N^{2}, N^{2}, N^{7}, N^{7}\right.$-tetrakis(4-methoxyphenyl)-9H-carbazole-2,7-diamine) (Q197) and 9,9'-(2,2'-dimethoxy-1,1' binaphthyl-6,6'-diyl)bis $\left(N^{3}, N^{3}, N^{6}, N^{6}\right.$-tetrakis (4-methoxyphenyl)-9H-carbazole-3,6-diamine) (Q205). A reference HTM based on a 3,3'-biphenyl central core, 9,9'-(6,6'-dimethoxy-biphenyl-3,3'- diyl)bis $\left(N^{2}, N^{2}, N^{7}, N^{7}\right.$-tetrakis (4-methoxy-phenyl)-9H-carbazole-2,7diamine) (Q198), was prepared for a comparative study. The structures of Q197, Q198, and Q205 are shown in Fig. 1. The donor groups for the three HTMs are carbazole-bis(4-methoxyphenyl)-amine. The bis(4-methoxy-phenyl)-amine moiety is replaced on different positions of $9 H$-carbazole. The donor group of Q197 and Q198 is 2,7-carbazole-bis(4-methoxy-phenyl)amine, and that of Q205 is 3,6-carbazole-bis(4-methoxy-phenyl)amine. The spectra of the studied HTMs were investigated for their absorption ability in solution and on the perovskite film. The electrochemical measurements and theoretical calculations were conducted for determining energy levels and optimizing geometric structures of the HTMs. Their thermal stability was evaluated by differential scanning calorimetry (DSC) and thermogravimetry (TG). PSCs based on the BINOLbased HTMs were fabricated, and the corresponding photovoltaic performances were compared with that of device fabricated by the reference HTM. The results indicate that the HTM based on the BINOL central core has a great potential for constructing high-efficiency PSC.

\section{Experimental}

\subsection{Instrument and materials}

All reactions were carried out under argon conditions and solvents were distilled from analytical grade reagents. The BINOL, $\quad \mathrm{Pd}_{2}(\mathrm{dba})_{3}, \quad n$-butyllithium, $t$-BuONa, $(t \text {-Bu })_{3} \mathrm{P}$ were

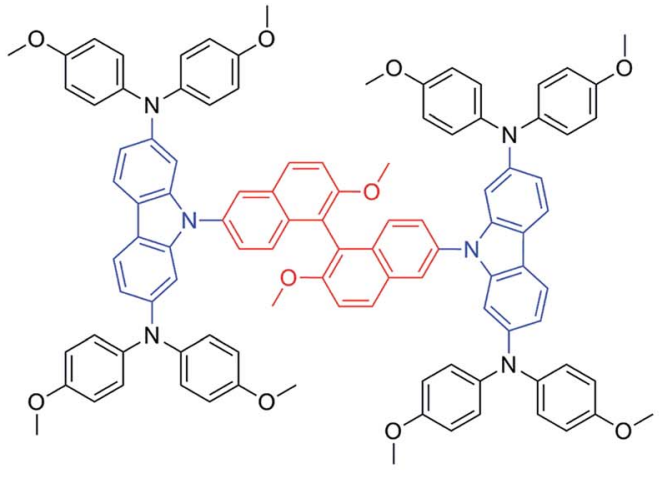

Q197<smiles></smiles>

Q205<smiles></smiles>

\section{Q198}

Fig. 1 Structures of Q205, Q197 and Q198. 
purchased from Energy Chemical (China). The lithium bis(trifluoromethanesulfonyl)imide (LiTFSI, $0.1 \mathrm{M}$ ) and 4-tert-pyridine (TBP) were purchased from Aldrich. The melting points of the samples were measured with a RY-1 melting point apparatus (Tianfen, China), and temperatures were uncorrected. ${ }^{1} \mathrm{H}$ NMR and ${ }^{13} \mathrm{C}$ NMR spectra were recorded on a Bruker AM-400 spectrometer. The reported chemical shifts were referenced against TMS. High resolution mass spectra (HRMS) were obtained with a Micromass GCT-TOF mass spectrometer.

\subsection{Synthesis}

The synthesis route for Q205, Q197 and Q198 are shown in Scheme 1. Intermediates from compound 1, 5, 6 and 7 were known compounds, and they were prepared by following synthetic methods reported in the literatures. ${ }^{46-50}$

Synthesis of $9,9^{\prime}$-(2,2'-dimethoxy-1,1'binaphthyl-6,6'-diyl)$\operatorname{bis}\left(N^{3}, N^{3}, N^{6}, N^{6}\right.$-tetrakis(4-methoxy-phenyl)-9H-carbazole-3,6diamine) (Q205). The compound Q205 was obtained by Buchwald-Hartwig reaction. Compound 1 (1 g, $1.69 \mathrm{mmol}$ ), compound $6(0.20 \mathrm{~g}, 0.42 \mathrm{mmol})$ and $t$-BuONa $(0.19 \mathrm{~g}, 8.73$ $\mathrm{mmol}$ ) was added to $20 \mathrm{~mL}$ of anhydrous toluene. The system was purged with nitrogen several times. Then $(t-\mathrm{Bu})_{3} \mathrm{P}(0.017 \mathrm{~g}$, $12 \% \mathrm{~mol})$ and $\mathrm{Pd}_{2}(\mathrm{bda})_{3}(0.039 \mathrm{~g}, 6 \% \mathrm{~mol})$ were placed in mixture solution and the reaction was refluxed for $24 \mathrm{~h}$. After cooling to room temperature and $20 \mathrm{~mL}$ water was added. Organic phase separation by ethyl acetate $(3 \times 20 \mathrm{~mL})$ and combined organic phases were dried with $\mathrm{MgSO}_{4}$ and purified by column chromatography petroleum ether/ethyl acetate $(\mathrm{PE} /$ EtOAc $\left.=2: 1, R_{\mathrm{f}}=0.2\right)$ to afford $0.50 \mathrm{~g}$ of $\mathbf{Q 2 0 5}$ with yield of $76 \%$ as green solids. Mp: $115-117{ }^{\circ} \mathrm{C} ;{ }^{1} \mathrm{H}$ NMR $(400 \mathrm{MHz}$, DMSO- $\left.d_{6}\right), \delta(\mathrm{ppm}): 8.24(4 \mathrm{H}, \mathrm{d}, J=7.3 \mathrm{~Hz}), 7.79-7.66(6 \mathrm{H}, \mathrm{m})$, $7.49(2 \mathrm{H}, \mathrm{d}, J=9.1 \mathrm{~Hz}), 7.34(4 \mathrm{H}, \mathrm{d}, J=8.8 \mathrm{~Hz}), 7.24(2 \mathrm{H}, \mathrm{d}, J=$ $9.0 \mathrm{~Hz}), 7.05(4 \mathrm{H}, \mathrm{d}, J=8.6 \mathrm{~Hz}), 6.86(16 \mathrm{H}, \mathrm{d}, J=9.0 \mathrm{~Hz}), 6.80$ $(16 \mathrm{H}, \mathrm{d}, J=9.0 \mathrm{~Hz}), 3.81(6 \mathrm{H}, \mathrm{s}), 3.68(24 \mathrm{H}, \mathrm{s}) .{ }^{13} \mathrm{C}$ NMR $(100$ MHz, pyridine- $\left.\mathrm{d}_{5}\right) \delta 156.05,155.11,142.84,142.08,138.23$, 133.38, 133.34, 130.13, 129.99, 127.44, 125.78, 125.40, 125.09, 124.52, 119.61, 117.40, 115.34, 114.95, 111.17, 56.34, 55.20. HRMS (ESI) $(\mathrm{m} / \mathrm{z})$ : $[\mathrm{M}]^{+}$calcd for $\mathrm{C}_{102} \mathrm{H}_{84} \mathrm{~N}_{6} \mathrm{O}_{10}, 1553.6249$; found: 1553.6327.

Synthesis of 9-benzyl-2,7-dibromo-9H-carbazole (2). $\mathrm{NaH}$ $(0.55 \mathrm{~g}, 23.08 \mathrm{mmol})$ was added in one portion to anhydrous DMF $(50 \mathrm{~mL})$. A solution of 2,7-dibromo- $9 \mathrm{H}$-carbazole $(5.00 \mathrm{~g}$, $15.38 \mathrm{mmol})$ in DMF $(20 \mathrm{~mL})$ was added dropwise. After one hour, benzyl bromide $(1.83 \mathrm{~mL}, 15.38 \mathrm{mmol})$ was added slowly. The suspension was stirred for another $6 \mathrm{~h}$ under nitrogen and carefully quenched with water. Then precipitate was filtrated to give white precipitate with quantitative yield, $6.38 \mathrm{~g} .{ }^{1} \mathrm{H}$ NMR (400 MHz, DMSO- $\left.d_{6}\right), \delta(\mathrm{ppm}): \delta 8.17(2 \mathrm{H}, \mathrm{d}, J=8.32 \mathrm{~Hz}), 7.92$ $(2 \mathrm{H}, \mathrm{s}), 7.39(2 \mathrm{H}, \mathrm{d}, J=8.32 \mathrm{~Hz}), 7.31-7.22(3 \mathrm{H}, \mathrm{m}), 7.12$ $(2 \mathrm{H}, \mathrm{d}, J=7.16 \mathrm{~Hz}), 5.71(2 \mathrm{H}, \mathrm{s})$.

Synthesis of 9-benzyl- $N^{2}, N^{2}, N^{7}, N^{7}$-tetrakis(4-methoxyphenyl)-9H-carbazole-2,7-diamine (3). Compound 2 (5.0 g, $12.04 \mathrm{mmol}), 4,4^{\prime}$-dimethoxydiphenylamine $(6.07 \mathrm{~g}, 26.5 \mathrm{mmol})$ and $t$-BuONa $(2.88 \mathrm{~g}, 30.01 \mathrm{mmol})$ were put in the round bottom flask equipped with stirring bar in anhydrous toluene $(60 \mathrm{~mL})$. Then $(t-\mathrm{Bu})_{3} \mathrm{P}(0.38 \mathrm{~g}, 15 \% \mathrm{~mol})$, and $\mathrm{Pd}_{2}(\mathrm{bda})_{3}(0.74 \mathrm{~g}, 4 \% \mathrm{~mol})$ were added under nitrogen. The mixture was refluxed and the reaction was followed by TLC (thin layer chromatography). Reaction was completed after 24 hours. The aqueous phase was extracted with $\mathrm{CH}_{2} \mathrm{Cl}_{2}(3 \times 50 \mathrm{~mL})$. The combined organic phases were dried with $\mathrm{MgSO}_{4}$ and purified by column chromatography (PE/EtOAc $=5: 1)$ to afford $6.5 \mathrm{~g}$ ( $76 \%$ yield) of compound $3 .{ }^{1} \mathrm{H}$ NMR $\left(400 \mathrm{MHz}, \mathrm{DMSO}_{6}\right) \delta 7.78(2 \mathrm{H}, \mathrm{d}, J=$ $8.44 \mathrm{~Hz}), 7.22(2 \mathrm{H}, \mathrm{d}, J=2.24 \mathrm{~Hz}), 7.21(1 \mathrm{H}, \mathrm{s}), 6.95(12 \mathrm{H}, \mathrm{d}, J=$ $8.96 \mathrm{~Hz}), 6.86(8 \mathrm{H}, \mathrm{d}, J=9 \mathrm{~Hz}), 6.66(2 \mathrm{H}, \mathrm{dd}, J=1.76 \mathrm{~Hz}, J=8.40$ $\mathrm{Hz}), 5.18(2 \mathrm{H}, \mathrm{s}), 3.73(12 \mathrm{H}, \mathrm{s})$.

Synthesis of $N^{2}, N^{2}, N^{7}, N^{7}$-tetrakis(4-methoxyphenyl)-9Hcarbazole-2,7-diamine (4). To a stirred of compound 3 (2.90 g, $4.07 \mathrm{mmol})$ in $120 \mathrm{~mL}$ DMSO was added $t$-BuOK $(40.74 \mathrm{mmol})$ at room temperature. The reaction mixture was stirred for $20 \mathrm{~min}$ and $\mathrm{O}_{2}$ was bubbled for the reaction with $3 \mathrm{~h}$. Then water $(200$ $\mathrm{mL}$ ) was poured to reaction solution and the mixture was stirred overnight. The precipitate was filtrated and purified by column chromatography with petroleum ether/ethyl acetate (PE/EtOAc $=4: 1)$ to give a light yellow solid compound $4(2.1 \mathrm{~g})$. Yield: $63 \% .{ }^{1} \mathrm{H}$ NMR (400 MHz, DMSO- $\left.d_{6}\right), \delta(\mathrm{ppm}): 7.74(2 \mathrm{H}, \mathrm{d}, J=$ $8.44 \mathrm{~Hz}), 6.99(8 \mathrm{H}, \mathrm{d}, J=9 \mathrm{~Hz}), 6.89(8 \mathrm{H}, \mathrm{d}, J=9 \mathrm{~Hz}), 6.76(2 \mathrm{H}, \mathrm{d}$, $J=1.84 \mathrm{~Hz}), 6.66(2 \mathrm{H}, \mathrm{dd}, J=1.96 \mathrm{~Hz}, J=8.44 \mathrm{~Hz}), 3.74(12 \mathrm{H}, \mathrm{s})$.

Synthesis of $9,9^{\prime}$-(2,2'-dimethoxy-1,1' $\mathbf{1}^{\prime}$ binaphthyl-6,6'-diyl) $\operatorname{bis}\left(N^{2}, N^{2}, N^{7}, N^{7}\right.$-tetrakis(4-methoxy-phenyl)-9H-carbazole-2,7diamine) (Q197). Compound 4 (1 g, $1.69 \mathrm{mmol})$, compound 6 $(0.20 \mathrm{~g}, 0.42 \mathrm{mmol})$ and $t$-BuONa $(0.19 \mathrm{~g}, 8.73 \mathrm{mmol})$ were added to $20 \mathrm{~mL}$ of anhydrous toluene. The system was purged with nitrogen several times. Then $(t-\mathrm{Bu})_{3} \mathrm{P}(0.017 \mathrm{~g}, 12 \% \mathrm{~mol})$ and $\operatorname{Pd}_{2}(\mathrm{bda})_{3}(0.039 \mathrm{~g}, 6 \% \mathrm{~mol})$ were added to the mixture solution and the reaction was refluxed for $24 \mathrm{~h}$. The reaction was cooled to room temperature and $20 \mathrm{~mL}$ water was added. The mixture were extracted by ethyl acetate and the combined organic phases were dried with $\mathrm{MgSO}_{4}$ and purified by column chromatography (petroleum ether/ethyl acetate $=2: 1$ ) to afford $0.50 \mathrm{~g}$ of Q197 with yield of $76 \%$ as brown solids. Mp: $185-186{ }^{\circ} \mathrm{C} ;{ }^{1} \mathrm{H}$ NMR (400 MHz, DMSO- $\left.d_{6}\right), \delta(\mathrm{ppm}): \delta 8.00(2 \mathrm{H}, \mathrm{d}, J=8.48 \mathrm{~Hz})$, $7.93(2 \mathrm{H}, \mathrm{s}), 7.77(4 \mathrm{H}, \mathrm{d}, J=8.44 \mathrm{~Hz}), 7.64(2 \mathrm{H}, \mathrm{d}, J=9.28 \mathrm{~Hz})$, $7.17(2 \mathrm{H}, \mathrm{d}, J=8.88 \mathrm{~Hz}), 7.00(2 \mathrm{H}, \mathrm{d}, J=9.00 \mathrm{~Hz}), 6.92(16 \mathrm{H}, \mathrm{d}, J$ $=8.60 \mathrm{~Hz}), 6.86(4 \mathrm{H}, \mathrm{s}), 6.75(16 \mathrm{H}, \mathrm{d}, J=8.56 \mathrm{~Hz}), 6.69(4 \mathrm{H}, \mathrm{d}, J$ $=9.20 \mathrm{~Hz}), 3.64(6 \mathrm{H}, \mathrm{s}), 3.59(24 \mathrm{H}, \mathrm{s}){ }^{13} \mathrm{C} \mathrm{NMR}(100 \mathrm{MHz}$, DMSO- $\left.d_{6}\right) \delta 155.70,155.55,146.81,141.78,141.14,132.42$, 132.21, 129.88, 129.31, 126.67, 126.32, 125.10, 124.42, 120.54, $118.70,117.69,115.57,115.19,101.76,56.55,55.57$. HRMS (ESI) $(\mathrm{m} / \mathrm{z}): \quad[\mathrm{M}]^{+}$calcd for $\mathrm{C}_{102} \mathrm{H}_{84} \mathrm{~N}_{6} \mathrm{O}_{10}, 1553.6249$; found: 1553.6282.

Synthesis of $\quad 9,9^{\prime}$-(6,6'-dimethoxy-biphenyl-3,3'-diyl) $\operatorname{bis}\left(N^{2}, N^{2}, N^{7}, N^{7}\right.$-tetrakis(4-methoxy-phenyl)-9H-carbazole-2,7diamine) (Q198). Compound 4 (1 g, $1.69 \mathrm{mmol})$, compound 7 $(0.15 \mathrm{~g}, 0.42 \mathrm{mmol})$ and $t$-BuONa $(0.19 \mathrm{~g}, 8.73 \mathrm{mmol})$ were added to $20 \mathrm{~mL}$ of anhydrous toluene. The system was purged with nitrogen several times. Then $(t-\mathrm{Bu})_{3} \mathrm{P}(0.017 \mathrm{~g}, 12 \% \mathrm{~mol})$ and $\mathrm{Pd}_{2}(\mathrm{bda})_{3}(0.039 \mathrm{~g}, 6 \% \mathrm{~mol})$ were added to the mixture and the reaction was refluxed for $24 \mathrm{~h}$. After cooling to room temperature $20 \mathrm{~mL}$ water was added to the reaction mixture. Organic phase separation by ethyl acetate $(3 \times 20 \mathrm{~mL})$ and combined organic phases were dried with $\mathrm{MgSO}_{4}$ and purified by column chromatography (petroleum ether/ethyl acetate $=2: 1$ ) to 
afford $0.50 \mathrm{~g}$ Q198 with yield of 64\% as brown solids. Mp: 176$178{ }^{\circ} \mathrm{C} ;{ }^{1} \mathrm{H}$ NMR $\left(400 \mathrm{MHz}, \mathrm{DMSO}-d_{6}\right), \delta(\mathrm{ppm}): 7.79(4 \mathrm{H}, \mathrm{d}, J=$ $8.40 \mathrm{~Hz}), 7.31(2 \mathrm{H}, \mathrm{d}, J=8.20 \mathrm{~Hz}), 6.99(3 \mathrm{H}, \mathrm{d}, J=8.80 \mathrm{~Hz}), 6.87$ $(19 \mathrm{H}, \mathrm{d}, J=8.12 \mathrm{~Hz}), 6.67-6.60(22 \mathrm{H}, \mathrm{m}), 3.62(6 \mathrm{H}, \mathrm{s}), 3.48(24 \mathrm{H}$, s). ${ }^{13} \mathrm{C}$ NMR (100 MHz, DMSO- $\left.d_{6}\right) \delta 156.32,155.85,147.01$, 142.52, 140.96, 129.31, 129.12, 128.95, 128.46, 127.76, 126.88, 120.56, 117.13, 115.20, 113.35, 56.23, 55.42. HRMS (ESI) $(\mathrm{m} / \mathrm{z})$ : $[\mathrm{M}]^{+}$calcd for $\mathrm{C}_{94} \mathrm{H}_{85} \mathrm{~N}_{6} \mathrm{O}_{10}, 1457.6249$; found: 1457.6327 .

\subsection{Spectral, electrochemical and thermal stability measurements}

The absorption spectra of Q205, Q197 and Q198 in solution and coated on mesoporous $\mathrm{TiO}_{2}$ and $\mathrm{TiO}_{2} / \mathrm{CH}_{3} \mathrm{NH}_{3} \mathrm{PbI}_{3}$ films were measured by SHIMADZU UV-2600 spectrophotometer. Fluorescence measurements were carried out with a HITACHI F-4500 fluorescence spectrophotometer. The morphology and structural properties of the films were analyzed using a ULTRA plus ZEISS field emission scanning electron microscope (SEM) and a Bruker AXS-D8 Advance X-ray diffractometer (XRD) using Cu $\mathrm{K} \alpha$ radiation.

Cyclic voltammetry (CV) measurements for Q205, Q197 and Q198 were performed on a Zennium electrochemical workstation (ZAHNER, Germany) using a three-electrode system. Tetrabutylammonium hexafluorophosphate $\left(n-\mathrm{Bu}_{4} \mathrm{NPF}_{6}\right)$ of $0.1 \mathrm{M}$ was added into a dichloromethane solution as electrolyte. An $\mathrm{Ag} / 0.01 \mathrm{M} \mathrm{AgNO}_{3}$ electrode (acetonitrile as solvent) was used as the reference electrode. In three-electrode system, a FTO conductive glass was used as the working electrode, and a platinized carbon electrode was used as the counter electrode. The scan rates were $10 \mathrm{mV} \mathrm{s}^{-1}$. The measurements were calibrated using ferrocene as standard. The redox potential of ferrocene internal reference is taken as $0.63 \mathrm{~V}$ versus NHE.

The thermal stability was determined by thermogravimetry (TG) and differential scanning calorimetry (DSC). TG analyses were performed on TG 209 F3 Tarsus (NETZSCH, Germany) at a heating rate of $10{ }^{\circ} \mathrm{C} \mathrm{min}^{-1}$ under nitrogen atmosphere. DSC analyses were conducted on DSC 200 F3 Maia (NETZSCH, Germany) at a heating rate of $10{ }^{\circ} \mathrm{C} \mathrm{min}^{-1}$ under a nitrogen atmosphere.

\subsection{Device fabrication}

FTO glass substrates (Nippon Sheet Glass, Hyogo, Japan, TEC14) were treated with mixing solution of hydrogen peroxide and ammonia and then were cleaned in solution of detergent, deionized water, acetone and ethanol, respectively. An isopropoxide solution (350 $\mu \mathrm{L}$ titanium(Iv) isopropoxide (97\%, Alfa Aesar) in $5 \mathrm{~mL}$ of ethanol with $0.013 \mathrm{M} \mathrm{HCl}$ ) was spin coated onto precleaned FTO substrate at $2000 \mathrm{rpm}$ for $30 \mathrm{~s}$ and sintering the resultant substrate at $500{ }^{\circ} \mathrm{C}$ for $30 \mathrm{~min}$ for obtaining a $30-50 \mathrm{~nm}$ dense blocking $\mathrm{TiO}_{2}\left(\right.$ bl-TiO$\left.{ }_{2}\right)$ layer. Then, $\mathrm{TiO}_{2}$ colloidal solution $\left(20 \mathrm{~nm} \mathrm{TiO}_{2}\right.$ : terpineol : ethanol $=1: 1: 3$, weight ratio) was spin-coated onto $\mathrm{bl}^{-\mathrm{TiO}_{2}}$ layer at $1500 \mathrm{rpm}$ for $30 \mathrm{~s}$. The resultant colloid-deposited FTO substrate was sintered at $500{ }^{\circ} \mathrm{C}$ for $30 \mathrm{~min}$ for attaining a mesoporous $\mathrm{TiO}_{2}\left(\mathrm{mp}-\mathrm{TiO}_{2}\right)$ layer with the thickness of 300-400 $\mathrm{nm}$. The film was immersed in $0.04 \mathrm{M}$ aqueous $\mathrm{TiCl}_{4}$ at $70{ }^{\circ} \mathrm{C}$ for $40 \mathrm{~min}$. After cooling to room temperature, the film was rinsed by deionized water and ethanol, respectively. Then the film was annealed at $500{ }^{\circ} \mathrm{C}$ for 30 min. The $\mathrm{CH}_{3} \mathrm{NH}_{3} \mathrm{PbI}_{3}$ perovskite was obtained in two steps. Firstly, $N, N$-dimethylformamide (DMF, 99.8\%, Aldrich) solution of $1.0 \mathrm{M} \mathrm{PbI}_{2}$ (99\%, Aldrich) were dropped onto the substrate of $\mathrm{FTO} / \mathrm{bl}-\mathrm{TiO}_{2} / \mathrm{mp}^{-\mathrm{TiO}_{2}}$ by spin-coating at $3000 \mathrm{rpm}$ for $30 \mathrm{~s}$, and then stirring the film at $70{ }^{\circ} \mathrm{C}$ for 15 min under $\mathrm{N}_{2}$ protection. Secondly, the $\mathrm{CH}_{3} \mathrm{NH}_{3} \mathrm{PbI}_{3}$ film was obtained by immerging the film in isopropanol (99.8\%, Aldrich) of $0.06 \mathrm{M} \mathrm{CH}_{3} \mathrm{NH}_{3} \mathrm{I}$ and drying it on a hot plate at $100{ }^{\circ} \mathrm{C}$ for $15 \mathrm{~min}$. After cooling down to room temperature, the HTM solution $(3.5 \mathrm{mg}$ in chlorobenzene of $1 \mathrm{~mL}$ ) was spin-coating on top of the $\mathrm{FTO} / \mathrm{Bl}_{-}-\mathrm{TiO}_{2} / \mathrm{mp}$ $\mathrm{TiO}_{2} / \mathrm{CH}_{3} \mathrm{NH}_{3} \mathrm{PbI}_{3}$ substrate at $2000 \mathrm{rpm}$ for $30 \mathrm{~s}$. The carbon cathode prepared by graphite powder $(20 \mathrm{~nm}$, Chenyang Graphite, China) were deposited on the film and scraped to a fixed active area of $0.09 \mathrm{~cm}^{2}$.

\subsection{Photovoltaic characterizations}

The photocurrent density voltage curves $(J-V)$ characteristics of the PSC devices were carried out using a Keithley 2400 digital source meter controlled by a computer and a standard AM1.5 solar simulator-Oriel 91160-1000 (300 W) SOLAR SIMULATOR $2 \times 2$ BEAM. The light intensity was calibrated by an Oriel reference solar cell. To prevent inflated photocurrents arising from stray light, a $0.09 \mathrm{~cm}^{2}$ black metal mask $\left(\mathrm{cm}^{2}\right)$ surrounded the active area was covered on a testing cell during all measurements. The action spectra of monochromatic incident photon-to-current conversion efficiency (IPCE) for solar cell were performed by using a commercial setup (QTest Station 2000 IPCE Measurement System, CROWNTECH, USA). Intensity modulated photovoltage spectroscopes (IMVS) was also measured by the Zennium electrochemical workstation (ZAHNER, Germany), in which a green light emitting diode (LED, 532 $\mathrm{nm}$ ) was modulated to yield light frequency ranging from 100 $\mathrm{mHz}$ to $10 \mathrm{kHz}$ and illumination intensity from 1 to $40 \mathrm{~mW}$ $\mathrm{cm}^{-2}$. Electron densities were measured by charge extraction technique as reported..$^{51}$

\section{Results and discussion}

\subsection{Spectral characterizations}

The light absorption property and optical energy gap ( $\left.E_{\mathrm{g}}^{\text {opt }}\right)$ of Q197, Q198 and Q205 were studied, and the spectra of the HTMs are shown in Fig. 2. The corresponding spectroscopic data are listed in Table 1. Fig. 2(a) shows the normalized UVvisible absorption and fluorescence emission spectra of the three HTMs in dichloromethane. The maximum absorption wavelength $\left(\lambda_{\mathrm{abs}}^{\max }\right)$ of Q197, Q198 and Q205 are located at $389 \mathrm{~nm}, 389 \mathrm{~nm}$ and $307 \mathrm{~nm}$, respectively. The absorption bands of Q197 and Q198 exhibited a red shift compared to Q205, and this may be due to the introduction of 4-methoxyphenyl-amine substituted on 2,7-positions of $9 \mathrm{H}$-carbazole extending the conjugation length of Q197 and Q198. The molar extinction coefficient of Q197, Q198 and Q205 are $62224 \mathbf{M}^{-1}$ $\mathrm{cm}^{-1}, 51966 \mathrm{M}^{-1} \mathrm{~cm}^{-1}$, and $109075 \mathrm{M}^{-1} \mathrm{~cm}^{-1}$, respectively (Fig. 2(b)). Obviously, Q205 and Q197 exhibit higher molar 
<smiles>COc1ccc(N(c2ccc(OC)cc2)c2ccc3[nH]c4ccc(N(c5ccc(OC)cc5)c5ccc(OC)cc5)cc4c3c2)cc1</smiles>

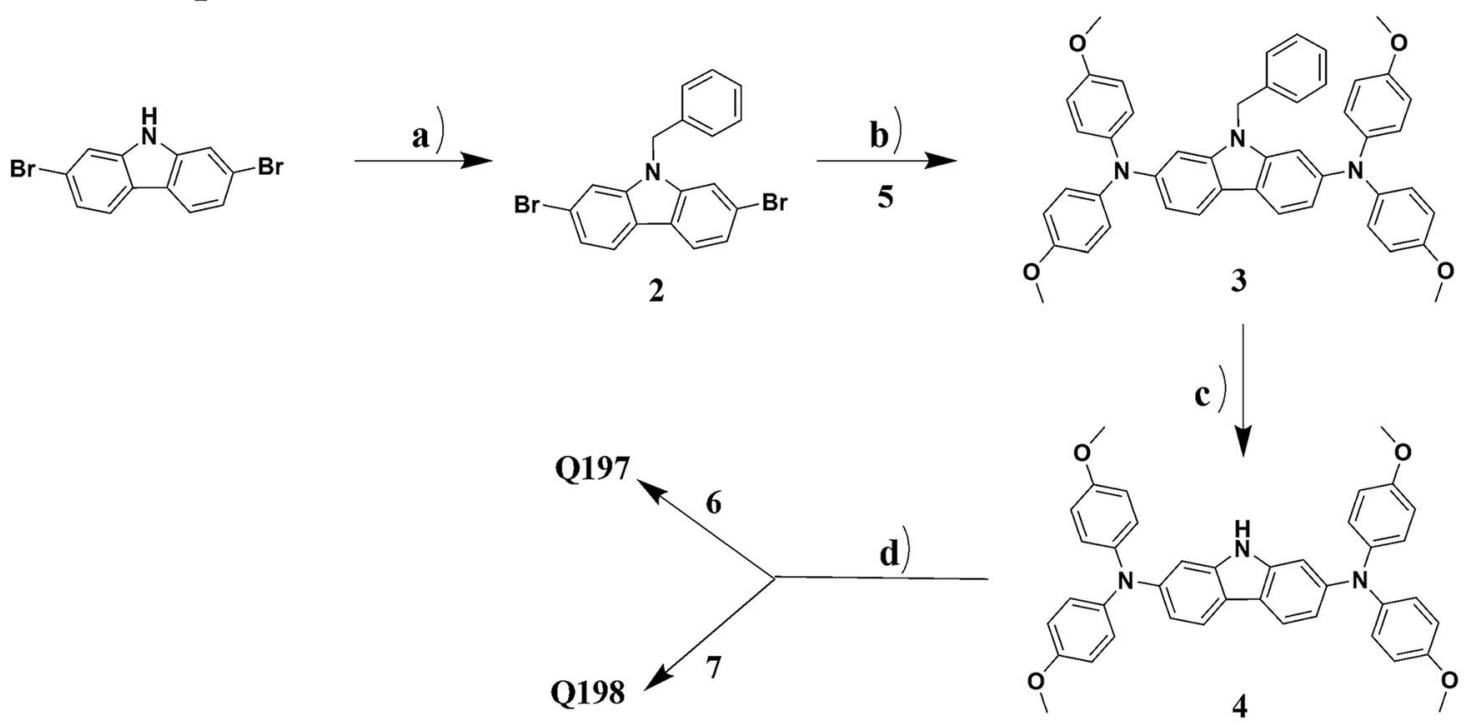

5:<smiles>COc1ccc(Nc2ccc(OC)cc2)cc1</smiles>

6:<smiles>COc1ccc2cc(Br)ccc2c1-c1c(OC)ccc2cc(Br)ccc12</smiles>

7:<smiles>COc1ccc(Br)cc1-c1cc(Br)ccc1OC</smiles>

Scheme 1 The synthesis route of Q205, Q197 and Q198. Conditions: (a) benzyl bromide, NaH, DMF, RT, 6 h, quantitative yield; (b) 4,4'dimethoxydiphenylamine, $\mathrm{Pd}_{2}(\mathrm{bda})_{3},(t-\mathrm{Bu})_{3} \mathrm{P}, t$-BuONa, toluene, reflux, overnight; (c) $t$-BuOK, DMSO, $\mathrm{O}_{2}, \mathrm{rt}$, overnight, $(63 \%) ;(d) \mathrm{Pd}_{2}(\mathrm{bda})_{3},(t-$ $\mathrm{Bu})_{3} \mathrm{P}, \mathrm{t}-\mathrm{BuONa}$, toluene, reflux, $24 \mathrm{~h}$.

extinction coefficient than Q198. The maximum emission wavelength $\left(\lambda_{\mathrm{fl}}^{\max }\right)$ of Q205, Q197 and Q198, are $476 \mathrm{~nm}, 428 \mathrm{~nm}$ and $427 \mathrm{~nm}$, and the corresponding optical band gaps $\left(E_{\mathrm{g}}^{\mathrm{opt}}\right)$ calculated from the spectroscopic data are $2.60 \mathrm{eV}, 2.90 \mathrm{eV}$ and $2.90 \mathrm{eV}{ }^{28}$ respectively. Fig. 2(c) displays the absorption spectra of $\mathrm{HTMs}$ coated on $\mathrm{TiO}_{2}\left(\mathbf{Q} 205 / \mathrm{TiO}_{2}, \mathbf{Q 1 9 7} / \mathrm{TiO}_{2}\right.$ and Q198/ $\left./ \mathrm{TiO}_{2}\right)$ and HTMs coated on perovskite $\left(\mathrm{CH}_{3} \mathrm{NH}_{3} \mathrm{PbI}_{3}\right) / \mathrm{TiO}_{2}$ films (Q205/CH $/ \mathrm{CH}_{3} \mathrm{NH}_{3} \mathrm{PbI}_{3} / \mathrm{TiO}_{2}, \quad \mathbf{Q 1 9 7} / \mathrm{CH}_{3} \mathrm{NH}_{3} \mathrm{PbI}_{3} / \mathrm{TiO}_{2}$ and Q198/ $\left./ \mathrm{CH}_{3} \mathrm{NH}_{3} \mathrm{PbI}_{3} / \mathrm{TiO}_{2}\right)$. The Q205/TiO 2, Q197/TiO 2 and Q198/ $\mathrm{TiO}_{2}$ films mainly exhibit UV absorption. The Q205/ $/ \mathrm{CH}_{3} \mathrm{NH}_{3}-$ $\mathrm{PbI}_{3} / \mathrm{TiO}_{2}, \mathrm{Q} 197 / \mathrm{CH}_{3} \mathrm{NH}_{3} \mathrm{PbI}_{3} / \mathrm{TiO}_{2}$ and $\mathbf{Q 1 9 8} / \mathrm{CH}_{3} \mathrm{NH}_{3} \mathrm{PbI}_{3} / \mathrm{TiO}_{2}$ films display an enhancement of absorption in the visible range from 400 to $750 \mathrm{~nm}$, comparing to $\mathrm{CH}_{3} \mathrm{NH}_{3} \mathrm{PbI}_{3} / \mathrm{TiO}_{2}$ film.

\subsection{Quantum chemical calculations}

The electronic properties and geometries of Q205, Q197 and Q198 were investigated by quantum chemical calculations. DFT at the B3LYP/6-31g level was used to optimize the geometric structures of the three HTMs. All structural optimization and energy calculations were performed using the GAUSSIAN 09 program. The optimized structures of Q205, Q197 and Q198 are shown in Fig. S1 (ESI + ), and the atoms are numbered. The selected bond angles and bond lengths of Q205, Q197 and Q198 are presented in Table S1. $\dagger$ The length of $\mathrm{C}-\mathrm{N}$ bond binding $9 \mathrm{H}^{-}$ carbazole and (4-methoxy-phenyl)-amine on 3,6-substituted position of Q205 is $1.430 \AA$, and that on 2,7-substituted position of Q197 is shorter (1.426 $)$ ). The representative dihedral angles of the three HTMs are marked, as shown in Fig. S2. $\dagger$ The two naphthalene rings of BINOL have a 3D structure with a dihedral angle of $75.427^{\circ}$ in Q205 and 99.341 in Q197. The frontier orbitals of molecules are also studied (Fig. 3). The highest occupied molecular orbital (HOMO) and the lowest unoccupied molecular orbital (LUMO) of three HTMs were simulated using Gaussian 09 program. The HOMO of Q205, Q197 and Q198 is localized in the carbazole-diarylamine part, and the LUMO mainly localized in the central core. It is indicated that a photoinduced electron transfer can occur in the HTM compounds by the HOMO-LUMO excitation. 

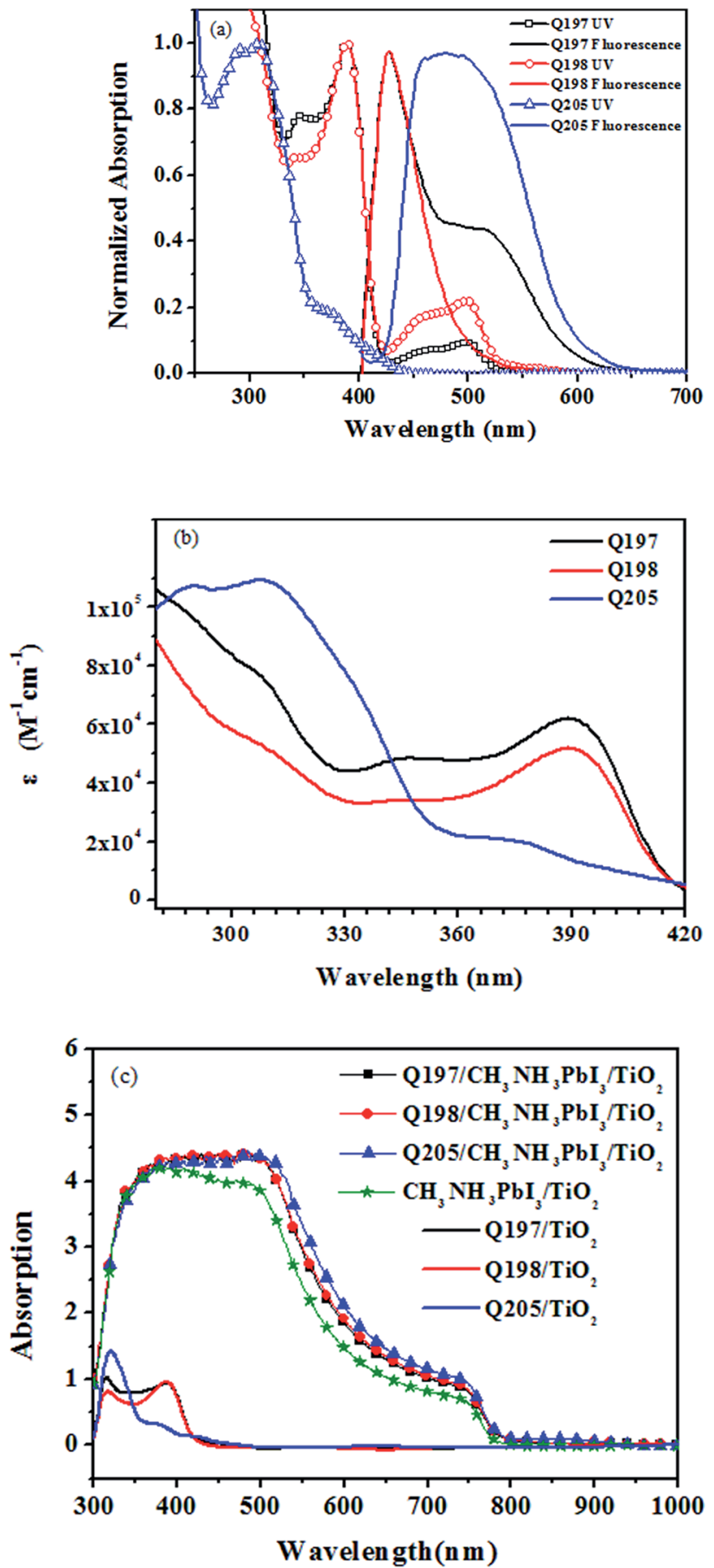

Fig. 2 (a) Normalized absorption and fluorescence emission spectra of HTMs in dichloromethane solution. (b) The corresponding molar extinction coefficient of absorption spectra in dichloromethane solution. (c) UV-vis spectra of $\mathrm{HTMs}$ on $\mathrm{TiO}_{2} \mathrm{HTMs}$ on perovskite $\left(\mathrm{CH}_{3} \mathrm{NH}_{3} \mathrm{Pbl}_{3}\right) / \mathrm{TiO}_{2}$ and perovskite $\left(\mathrm{CH}_{3} \mathrm{NH}_{3} \mathrm{Pbl}_{3}\right) / \mathrm{TiO}_{2}$ in thin films.

\subsection{Electrochemical measurements}

The accurate HOMO level of Q205, Q197 and Q198 were determined by cyclic voltammetry (CV), and the CV curves are shown in Fig. 4. Table 2 lists the corresponding electrochemical data of the three HTMs. The HOMO levels of Q205, Q197 and Q198 calculated from $\mathrm{CV}$ are $-5.34 \mathrm{eV},-5.39 \mathrm{eV}$ and $-5.40 \mathrm{eV}$,
Table 1 The spectroscopic data of compound Q205, Q197 and Q198 employed in solution and in solid-state films

\begin{tabular}{lllll}
\hline Compound & $\begin{array}{l}\lambda_{\mathrm{abs}}^{\max }(\mathrm{nm}) \\
\text { soln }\end{array}$ & $\begin{array}{l}\lambda_{\mathrm{fl}}^{\max }(\mathrm{nm}) \\
\text { soln }\end{array}$ & $\varepsilon / \mathbf{M}^{-1} \mathrm{~cm}^{-1}$ & $\begin{array}{l}\lambda_{\mathrm{abs}}^{\max }(\mathrm{nm}) \\
\text { film }\end{array}$ \\
\hline Q197 & 389 & 428 & 62224 & 316 \\
& & & & 387 \\
Q198 & 389 & 427 & 51966 & 316 \\
& & & & 387 \\
Q205 & 307 & 476 & 109075 & 320
\end{tabular}

respectively. ${ }^{52}$ The HOMO levels of the three HTMs are between that of $\mathrm{CH}_{3} \mathrm{NH}_{3} \mathrm{PbI}_{3}(-5.43 \mathrm{eV})$ and the carbon counter electrode $(-5.0 \mathrm{eV}) .^{27,53-55}$ The LOMO levels of Q205, Q197 and Q198 are $-2.38 \mathrm{eV},-2.36 \mathrm{eV}$ and $-2.37 \mathrm{eV}$, respectively. The LUMO value of $\mathrm{HTMs}$ higher than that of $\mathrm{CH}_{3} \mathrm{NH}_{3} \mathrm{PbI}_{3}(-3.93 \mathrm{eV})$ favors electron injection efficiency on the surface of $\mathrm{CH}_{3} \mathrm{NH}_{3}$ $\mathrm{PbI}_{3} / \mathrm{HTM}^{16}$

\subsection{Thermal properties}

The thermal stability of the studied HTMs was tested by thermogravimetry (TG) and differential scanning calorimetry (DSC). The TG and DSC results were plotted in Fig. 5. The three HTMs exhibit high thermal decomposition temperature $\left(T_{\mathrm{d}}\right)$ above $420{ }^{\circ} \mathrm{C}$ (Fig. 5(a)). Q205, Q197 and Q198 have a high glass transition temperature $\left(T_{\mathrm{g}}\right)$ of $188{ }^{\circ} \mathrm{C}, 168{ }^{\circ} \mathrm{C}$ and $157{ }^{\circ} \mathrm{C}$ (Fig. 5(b)). The naphthyl on the BINOL core has a stronger rigidity than the phenyl on the $3,3^{\prime}$-biphenyl core, and the BINOL core has a more twisted dihedral angle than the 3,3'biphenyl core (Fig. S2 $\dagger$ ). The much higher $T_{\mathrm{g}}$ values of $\mathbf{Q 2 0 5}$ and Q197 are possibly benefited from the more twisted structure of their BINOL central core than that of 3,3'-biphenyl core on the reference HTM (Q198). ${ }^{56,57}$ In spin coating procedure, all of them can form amorphous films in solid states without molecular aggregation.

\subsection{Device performance}

The morphology of spin-coated thin films of Q205, Q197 and Q198 on perovskite surface was measured by SEM (Fig. 6). The $\mathrm{CH}_{3} \mathrm{NH}_{3} \mathrm{PbI}_{3}$ were prepared by two-step deposition. As shown in Fig. 6(a)-(c), the HTM films are transparent and uniform, and the result is in agreement with their good thermal stability showing no aggregation. Fig. 6(d) gives the cross-section SEM morphology of PSC, and the film thickness of HTM is $150 \mathrm{~nm}$.

The photovoltaic performances of PSCs fabricated by BINOLbased HTMs were investigated by $J-V$ characteristics under illumination of $100 \mathrm{~mW} \mathrm{~cm}{ }^{-2}$, and PSCs based on the reference HTM were also tested. In PSC devices, carbon counter electrode was used to replace noble metallic materials. At first, the conditions of HTM concentration, doping amount of LiTFSI and TBP were optimized. The results are shown in Fig. S3 and $\mathrm{S} 4, \dagger$ and the corresponding photovoltaic parameters are listed in Tables S2-S4 (ESI $\dagger$ ). As shown in Fig. S3(b) and Table S2, $\dagger$ the best performance of Q197-based PSC is obtained under conditions of Q197 (70 $\left.\mathrm{mg} \mathrm{mL}^{-1}\right)$ doping Li-TFSI/TBP (30 mM/120 
HOMO
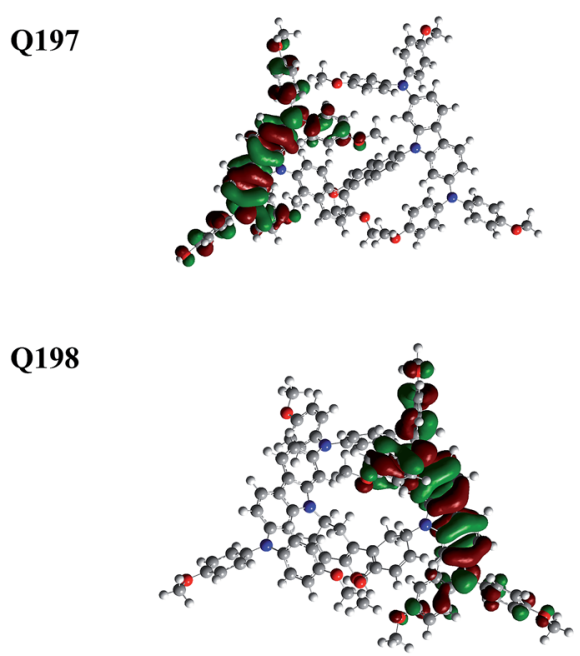

Q205

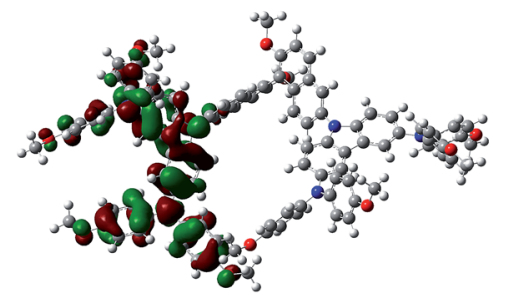

LUMO
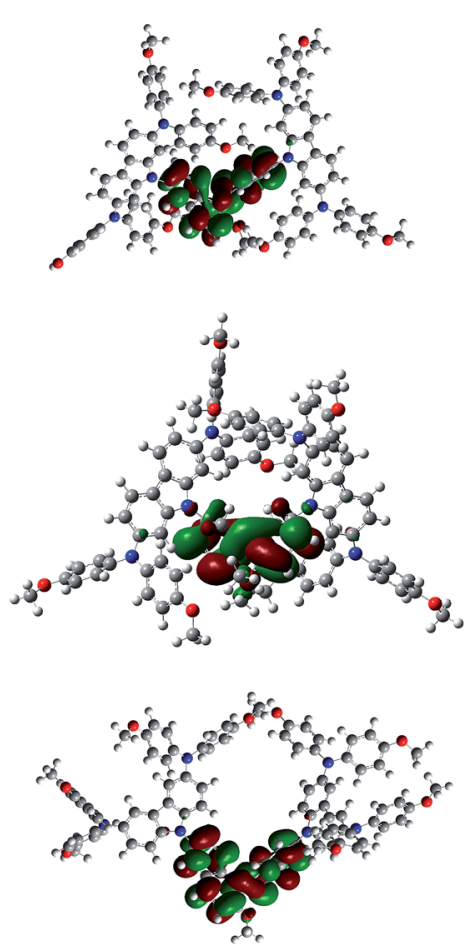

Fig. 3 The frontier orbitals of Q205, Q197 and Q196.

$\mathrm{mM}$ ), leading to a short-circuit current density $\left(J_{\mathrm{sc}}\right)$ of $16.53 \mathrm{~mW}$ $\mathrm{cm}^{-2}$, an open-circuit voltage $\left(V_{\mathrm{oc}}\right)$ of $897 \mathrm{mV}$, a fill factor (FF) of 0.56 , and a PCE of $8.38 \%$. This result is comparable to PSC based on commercial spiro-OMeTAD measured under the same condition (8.73\%). At the same doping level, devices based on Q205 and Q198 got the PCE of 5.38\% and 5.21\%, respectively (Tables S2-S4 $\dagger$ ). When $\mathbf{Q 1 9 7}$ of $30 \mathrm{mg} \mathrm{mL}^{-1}$ and $50 \mathrm{mg} \mathrm{mL}^{-1}$ was respectively used with addition of Li-TFSI/TBP $(30 \mathrm{mM} / 120$

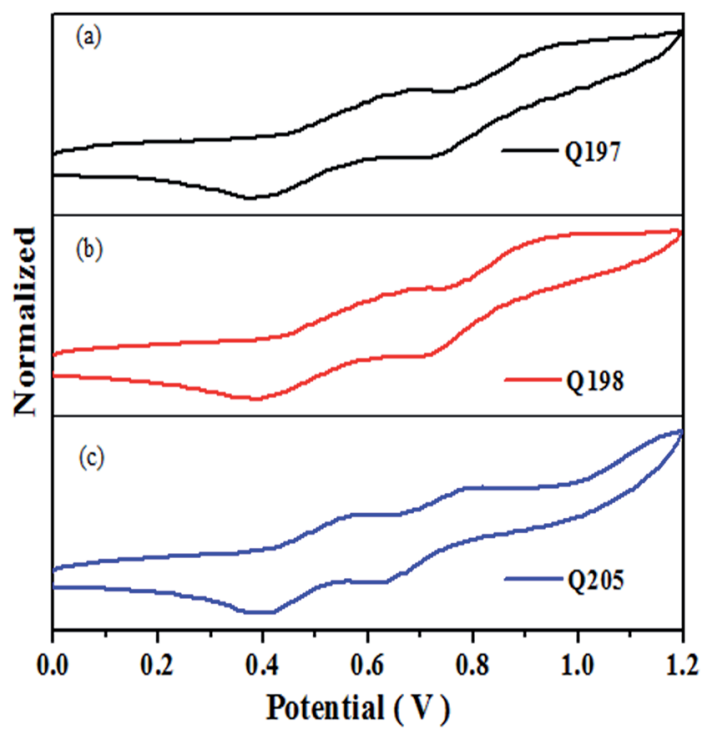

Fig. 4 Cyclic voltagrams of Q205, Q197 and Q198.
$\mathrm{mM}$ ), the corresponding PCE are $4.09 \%$ and 5.29\%. When the concentration of Q197 was increased from $70 \mathrm{mg} \mathrm{mL}^{-1}$ to $100 \mathrm{mg} \mathrm{mL}$ (Li-TFSI/TBP $(30 \mathrm{mM} / 120 \mathrm{mM})$ ), the PCE decreased to 5.59\%. Too higher concentration of HTM will form too thick solid-state film by spin coating, possibly resulting in the acceleration of electron recombination rate at the $\mathrm{CH}_{3}$ $\mathrm{NH}_{3} \mathrm{PbI}_{3} / \mathrm{HTM}$ interface. PSC based on Q197 without doping showed a $J_{\mathrm{sc}}$ of $11.14 \mathrm{~mW} \mathrm{~cm} \mathrm{~cm}^{-2}$, a $V_{\mathrm{oc}}$ of $645 \mathrm{mV}$, a FF of 0.34 , and a PCE of $2.45 \%$. The doping of Li-TFSI and TBP has a positive impact on the photovoltaic action of HTM in PSC. As mentioned above, the optimal dosage of Li-TFSI and TBP for Q197 are $30 \mathrm{mM}$ and $120 \mathrm{mM}$, respectively. When the adding amount of Li-TFSI was kept at $30 \mathrm{mM}$, the PCE of PSC based on Q197 doping TBP of $60 \mathrm{mM}$ and $200 \mathrm{mM}$ are $6.37 \%$ and $8.08 \%$, respectively. In addition, when the adding amount of TBP was kept constant, the PCE of PSC based on Q197 doping Li-TFSI of $60 \mathrm{mM}$ and $15 \mathrm{mM}$ are $3.91 \%$ and $4.18 \%$, respectively. The positions of the end groups also have a great impact on the cell performance. In this work, the solubility of Q197 and Q198 based on 2,7-carbazole-bis(4-methoxy-phenyl)-amine in

Table 2 The electrochemical data of Q205, Q197 and Q198

\begin{tabular}{llllll}
\hline Compound & $E_{\mathrm{pc}}(\mathrm{V})$ & $E_{\mathrm{pa}}(\mathrm{V})$ & $E_{\text {ox }, 1 / 2}(\mathrm{~V})$ & $E_{\text {Hомо }}(\mathrm{eV})$ & $E_{\mathrm{LUMO}}(\mathrm{eV})$ \\
\hline Q205 & 0.40 & 0.56 & 0.54 & -5.34 & -2.38 \\
Q197 & 0.39 & 0.67 & 0.59 & -5.39 & -2.36 \\
Q198 & 0.39 & 0.69 & 0.60 & -5.40 & -2.37
\end{tabular}



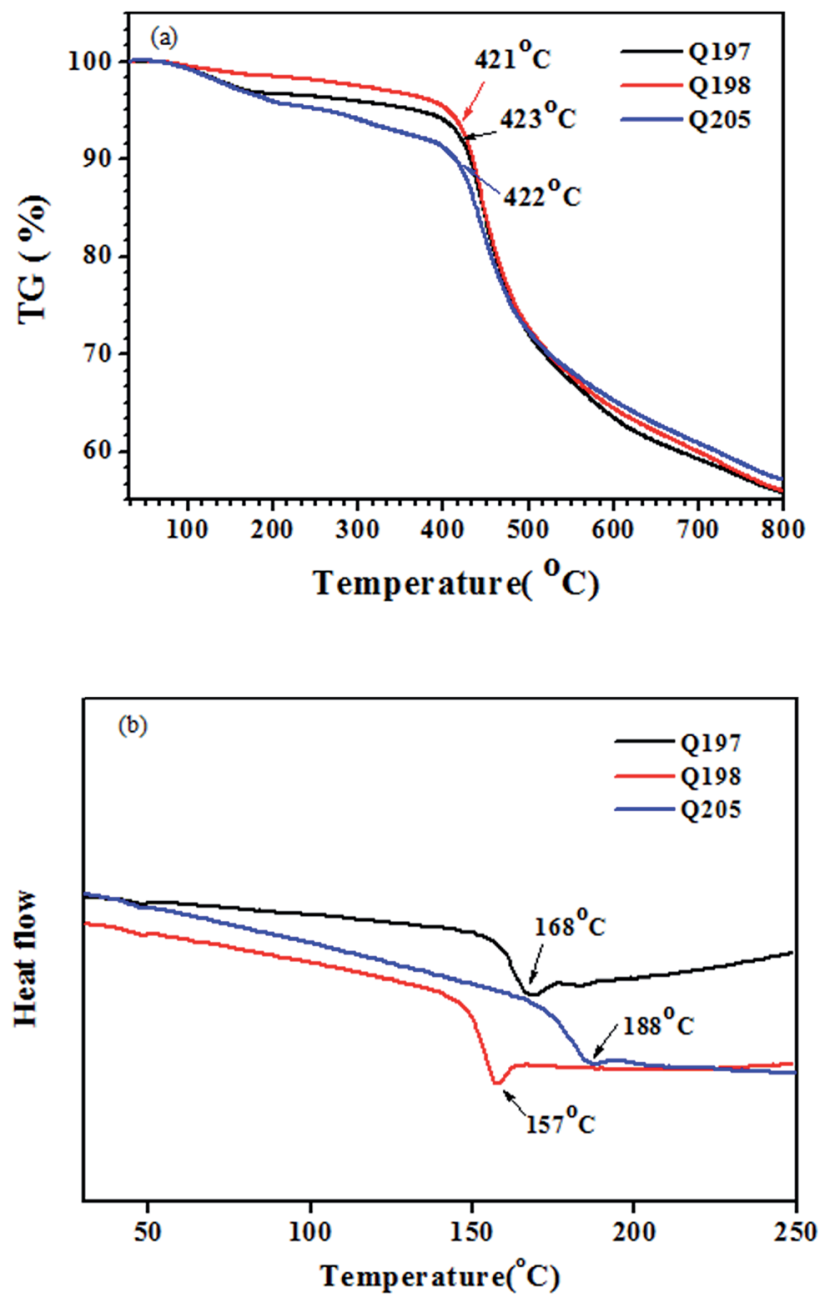

Fig. 5 (a) TG and (b) DSC curves of Q205, Q197 and Q198.

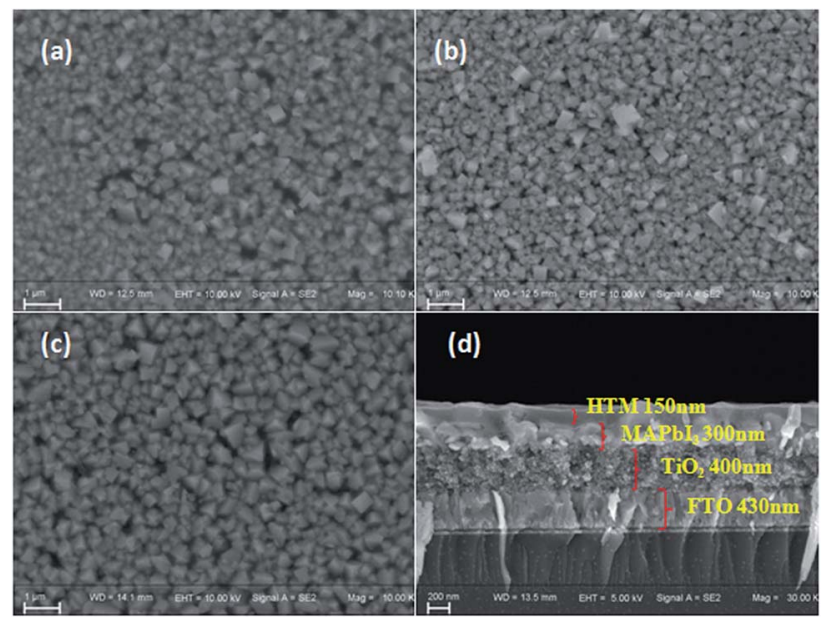

Fig. 6 Top SEM pictures of (a) Q197; (b) Q198; (c) Q205, and (d) crosssection SEM of PSC.

chlorobenzene is superior to that of Q205 based on 3,6-carbazole-bis(4-methoxy-phenyl)-amine. The solubility of Q205 was greatly enhanced when doping Li-TFSI/TBP of $30 \mathrm{mM} /$
$200 \mathrm{mM}$. As shown in Fig. S3(a) and Table S3, $\uparrow$ the optimized Q205-based PSC is fabricated under the condition of Q205 (60 $\mathrm{mg} \mathrm{mL}^{-1}$ ) doping Li-TFSI/TBP $(30 \mathrm{mM} / 200 \mathrm{mM})$, leading to a $J_{\text {sc }}$ of $13.23 \mathrm{~mW} \mathrm{~cm}^{-2}$, a $V_{\text {oc }}$ of $984 \mathrm{mV}$, a FF of 0.50 , and a PCE of 6.51\%. As a comparison, the reference HTM Q198-based PSC showed the highest PCE of 7.08\% under the condition of Q198 (70 $\mathrm{mg} \mathrm{mL} \mathrm{mL}^{-1}$ ) doping with Li-TFSI/TBP (30 mM/200 mM), yielding a $J_{\mathrm{sc}}$ of $16.69 \mathrm{~mW} \mathrm{~cm}{ }^{-2}$, a $V_{\text {oc }}$ of $863 \mathrm{mV}$, a FF of 0.49 . Therefore, the appropriate concentration of HTM concentration and doping amount of additives (Li-TFSI and TBP) improves the photovoltaic performances of PSC fabricated by BINOL-based HTM greatly.

Accordingly, $J-V$ measurements of PSC based on HTMs Q197/Q205/Q198 under illumination of $100 \mathrm{~mW} \mathrm{~cm}^{-2}$ and in dark were investigated. Fig. 7 shows the corresponding $J-V$ characteristics of PSCs and the incident photon-to-current conversion efficiency (IPCE) spectra of devices. ${ }^{58,59}$ The corresponding photovoltaic parameters are given in Table 3. From Fig. 7(a), PSC based on Q197 (8.38\%) exhibited better photovoltaic performance than that based on Q205 (6.51\%) and Q198
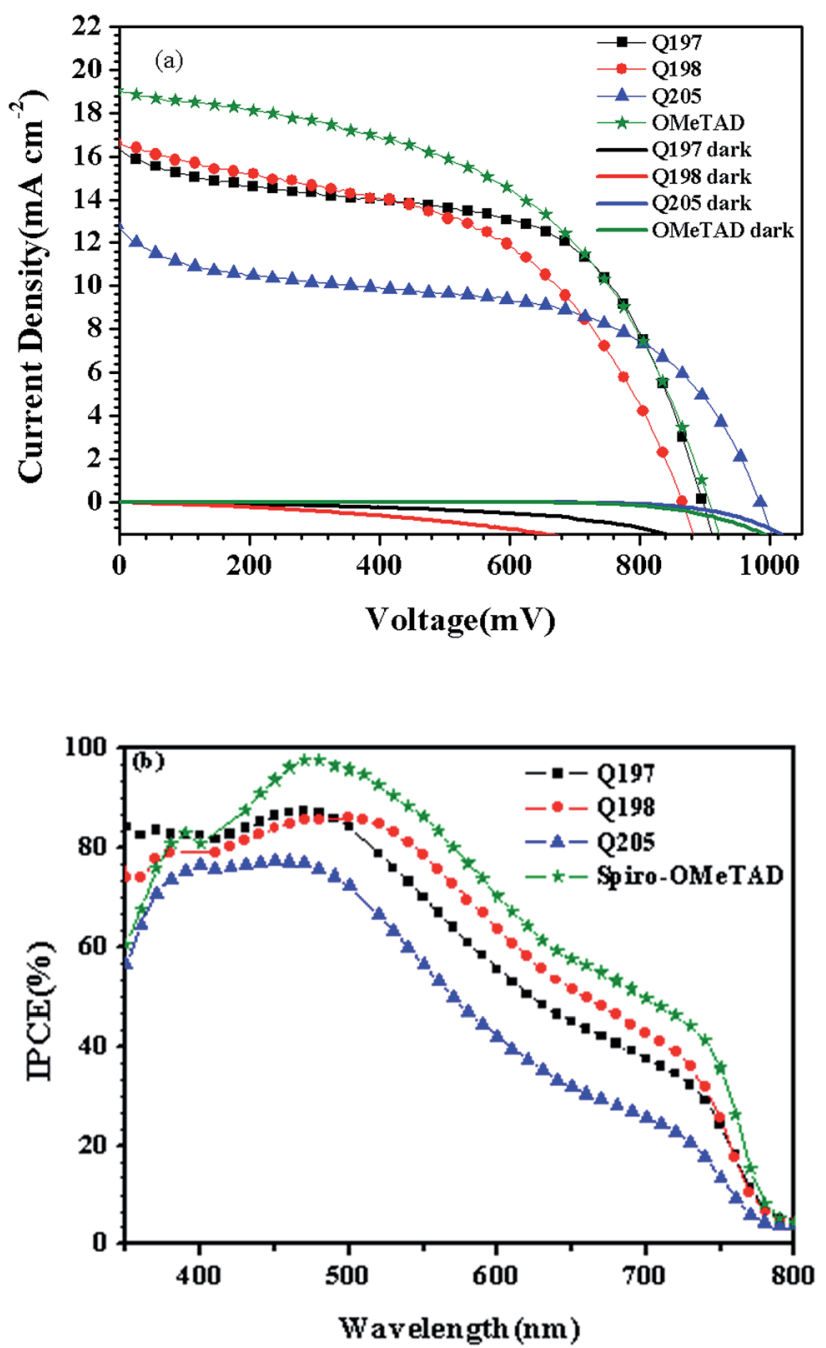

Fig. 7 (a) J-V and (b) IPCE characteristics of the optimal PSCs based on HTMs Q197Q198Q205\commerical spiro-OMeTAD. 
(7.08\%). The BINOL central core of Q197 is superior to the 3,3'biphenyl central core of Q198. The closer HOMO levels of Q197 $(-5.39 \mathrm{eV})$ and $\mathbf{Q 1 9 8}(-5.40 \mathrm{eV})$ to the valence band of $\mathrm{CH}_{3}$ $\mathrm{NH}_{3} \mathrm{PbI}_{3}$ than Q205 $(-5.34 \mathrm{eV})$ may promote holes to transfer from $\mathrm{CH}_{3} \mathrm{NH}_{3} \mathrm{PbI}_{3}$ to HTM layer. It is also shown in Fig. 7(a) that the dark current of PSC was increased in order of Q205 $<$ Q197 $<$ Q198. This result suggests that charge recombination of Q205 and Q197 was greatly reduced. ${ }^{60}$ The higher $V_{\text {oc }}$ value of Q205 (984 $\mathrm{mV}$ ) and Q197 (897 $\mathrm{mV}$ ) than Q198 (863 $\mathrm{mV}$ ) may caused by the decrease of charge recombination. ${ }^{46}$ Thus, BINOL-based HTMs has a great potential for the construction of highly efficient PSCs. The $J_{\text {sc }}$ of PSC increased in order of Q205 $(13.23 \mathrm{~mW}$ $\left.\mathrm{cm}^{-2}\right)<$ Q197 $\left(16.53 \mathrm{~mW} \mathrm{~cm} \mathrm{~cm}^{-2}\right) \approx$ Q198 (16.69 $\mathrm{mW} \mathrm{cm} \mathrm{cm}^{-2}$ ), which was in accordance with IPCE value (Fig. 7(b)).

To further evaluate the potential of the studied HTMs, time constant of electron recombination $\left(\tau_{\mathrm{n}}\right)$ was measured by intensity modulated photovoltage spectroscopy (IMVS) ${ }^{6 \mathbf{1}}$ (Fig. 8). As shown in Fig. 8, PSC based on Q197 and Q198 show a lager time constant of electron recombination and a higher electron density than that based on Q205. This result is agreement with that Q197 and Q198 exhibited higher $J_{\text {sc }}$ values than Q205. Based on the results of $J-V$ characteristics, it can be concluded that the change of donor arms of BINOL-based HTMs can be used to regulate the photovoltaic parameters of

Table $3 J-V$ characteristics of optimal photovoltaic parameters of PSC

\begin{tabular}{lllll}
\hline HTM & $J_{\mathrm{sc}} / \mathrm{mA} \mathrm{cm}^{-2}$ & $V_{\text {oc }} / \mathrm{V}$ & $\mathrm{FF}$ & $\eta \%$ \\
\hline Q197 $^{a}$ & 16.53 & 897 & 0.56 & 8.38 \\
Q198 $^{b}$ & 16.69 & 863 & 0.49 & 7.08 \\
Q205 $^{c}$ & 13.23 & 984 & 0.50 & 6.51 \\
Spiro-OMeTAD $^{b}$ & 18.98 & 906 & 0.51 & 8.73
\end{tabular}

${ }^{a} 70 \mathrm{mg} \mathrm{mL}{ }^{-1}$ HTM doped with $30 \mathrm{mM} \mathrm{Li-TFSi} / 120 \mathrm{mM}$ TBP. ${ }^{b} 70 \mathrm{mg}$ $\mathrm{mL}^{-1}$ HTM doped with $30 \mathrm{mM} \mathrm{Li}$-TFSi/200 mM TBP. ${ }^{c} 60 \mathrm{mg} \mathrm{mL}{ }^{-1}$ HTM doped with $30 \mathrm{mM} \mathrm{Li-TFSi/200} \mathrm{mM} \mathrm{TBP.}$

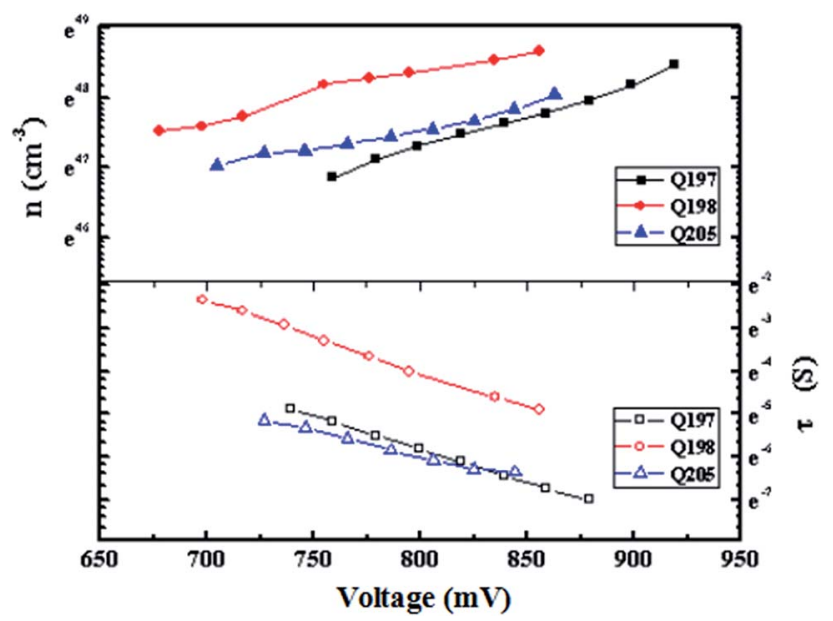

Fig. 8 Plots of the recombination time constant $\left(\tau_{n}\right)$ and electron density $(n)$ versus open circuit voltage of PSCs based on HTMs Q197Q198Q205.
PSCs. Q197 containing 2,7-carbazole-bis(4-methoxy-phenyl)amine groups exhibits higher $J_{\mathrm{sc}}$. Q205 bearing 3,6-carbazolebis(4-methoxy-phenyl)-amine shows lager $V_{\text {oc }}$. Moreover, Table S5 $\dagger$ lists photovoltaic parameters of eight cells fabricated by Q197. It is shown that PSCs fabricated by BINOL-based HTMs displayed replicability, which is good for BINOL-based HTMs to become a promising candidate for the fabrication of efficient PSCs.

\section{Conclusion}

Two star-shaped HTMs based on a 1,1'-bi-2-naphthol (BINOL) central core for perovskite solar cells are synthesized by a facile route. BINOL is aimed to be used as a bridged/spiro core for preparing comparable HTM to commercial spiro-OMeTAD. The BINOL core is armed with end groups of 3,6-carbazole-bis(4methoxy-phenyl)-amine (Q205) and 2,7-carbazole-bis(4methoxy-phenyl)-amine (Q197), separately. A reference HTM based on a 3,3'-biphenyl core and 2,7-carbazole-bis(4-methoxyphenyl)-amine was prepared for comparison (Q198). The optimized geometric structures display the two naphthalene rings of BINOL with a dihedral angle of $75.427^{\circ}$ in $\mathbf{Q 2 0 5}$ and $99.341^{\circ}$ in Q197. The two phenyl rings of the 3,3'-biphenyl core on the reference HTM show a dihedral angle of $114.004^{\circ}$. Thus, BINOLbased HTMs with more twisted structures display much higher $T_{\mathrm{g}}$ values $\left(T_{\mathrm{g}}>160{ }^{\circ} \mathrm{C}\right)$ than the reference HTM. CV data show Q197 containing 2,7-carbazole-bis(4-methoxy-phenyl)-amine have deeper HOMO level than Q205 containing 3,6-carbazolebis(4-methoxy-phenyl)-amine, leading to closer energy gap to the valence band of $\mathrm{CH}_{3} \mathrm{NH}_{3} \mathrm{PbI}_{3} . J-V$ characteristics results show device based on Q197 display a higher $J_{\mathrm{sc}}$ and the highest PCE (8.38\%) than Q205 (6.51\%), which is comparable to that fabricated by commercial spiro-OMeTAD (8.73\%). Device fabricated by Q205 shows a much larger $V_{\text {oc }}(983 \mathrm{mV})$. The dark current measurements indicate the BINOL-based HTMs effectively reduced charge recombination, as compared to the reference HTM. IMVS measurements also show BINOL-based HTMs have large time constant of electron recombination and high electron density. Therefore, BINOL is a promising bridge/ spiro building block for fabricating highly efficient PSC, and the photovoltaic parameters of device based on this new type HTM can be flexibly tunable by structural modification.

\section{Acknowledgements}

This work was supported by the National Natural Science Foundation of China $(21376179,21506164)$.

\section{References}

1 D. Q. Bi, B. Xu, P. Gao, L. C. Sun, M. Grätzel and A. Hagfeldt, Nano Energy, 2016, 23, 138.

2 T. Salim, S. Sun, Y. Abe, A. Krishna, A. C. Grimsdale and Y. M. Lam, J. Mater. Chem. A, 2015, 3, 8943.

3 L. K. Ono, M. R. Leyden, S. H. Wang and Y. B. Qi, J. Mater. Chem. A, 2016, 4, 6693. 
4 M. Park, J. S. Park, K. Han and J. Young, J. Mater. Chem. A, 2016, 4, 11307.

5 N. G. Park, CrystEngComm, 2016, 18, 5977.

6 T. Salim, S. Y. Sun, Y. Abe, A. Krishna, A. C. Grimsdale and Y. M. Lam, J. Mater. Chem. A, 2015, 3, 8943.

7 H. W. Chen, Y. Hou, C. E. Halbig, S. Chen, H. Zhang, N. Li, F. Guo, X. F. Tang, N. Gasparini, I. Levchuk, S. Kahmann, C. O. R. Quiroz, A. Osvet, S. Eigler and C. J. Brabec, J. Mater. Chem. A, 2016, 4, 11604.

8 T. C. Sum and N. Mathews, Energy Environ. Sci., 2014, 7, 2518.

9 Y. X. Zhao and K. Zhu, Chem. Soc. Rev., 2016, 45, 655.

10 S. Q. Luo and W. A. Daoud, J. Mater. Chem. A, 2015, 3, 8992.

11 U. Bach, D. Lupo, P. Comte, J. E. Moser, F. Weissortel, J. Salbeck, et al., Nature, 1998, 395, 583.

12 J. Liu, Y. Z. Wu, C. J. Qin, X. D. Yang, T. Yasuda, A. Islam, K. Zhang, W. Q. Peng, W. Chen and L. Y. Han, Energy Environ. Sci., 2014, 7, 2963.

13 S. Kazim, F. J. Ramos, P. Gao, M. K. Nazeeruddin, M. Grätzel and S. Ahmad, Energy Environ. Sci., 2015, 8, 1816.

14 G. F. Gong, N. Zhao, D. Ni, J. Y. Chen, Y. Shen, M. K. Wang and G. L. Tu, J. Mater. Chem. A, 2016, 4, 3661.

15 Y. T. Shi, K. L. Hou, Y. X. Wang, K. Wang, H. C. Ren, M. Y. Pang, F. Chen and S. Zhang, J. Mater. Chem. A, 2016, 4, 5415.

16 H. Nishimura, N. Ishida, A. Shimazaki, A. Wakamiya, A. Saeki, L. T. Scott and Y. Murata, J. Am. Chem. Soc., 2015, 137, 15656.

17 H. Choi, J. W. Cho, M. S. Kangc and J. Ko, Chem. Commun., 2015, 51, 9305.

18 M. L. Petrus, T. Bein, T. J. Dingemans and P. Docampo, J. Mater. Chem. A, 2015, 3, 12159.

19 J. Wang, S. Wang, X. Li, L. Zhu, Q. Meng, Y. Xiao and D. Li, Chem. Commun., 2014, 50, 5829.

20 S. Lv, L. Han, J. Xiao, L. Zhu, J. Shi, H. Wei, Y. Xu, J. Dong, X. Xu, D. Li, S. Wang, Y. Luo, Q. Meng and X. Li, Chem. Commun., 2014, 50, 6931.

21 H. Choi, S. Park, S. Paek, P. Ekanayake, K. M. Nazeeruddinc and J. Ko, J. Mater. Chem. A, 2014, 2, 19136.

22 B. Xu, E. Sheibani, P. Liu, J. B. Zhang, H. N. Tian, N. Vlachopoulos, G. Boschloo, L. Kloo, A. Hagfeldt and L. C. Sun, Adv. Mater., 2014, 26, 6629.

23 N. J. Jeon, J. Lee, J. H. Noh, M. K. Nazeeruddin, M. S. Grätzel and S. I. Seok, J. Am. Chem. Soc., 2013, 135, 19087.

24 K. Do, H. Choi, K. Lim, H. Jo, J. W. Cho, M. K. Nazeeruddinc and J. Ko, Chem. Commun., 2014, 50, 10971.

25 S. Y. Ma, H. Zhang, N. Zhao, Y. B. Cheng, M. K. Wang, Y. Shen and G. L. Tu, J. Mater. Chem. A, 2015, 3, 12139.

26 T. Krishnamoorthy, F. Kunwu, P. P. Boix, H. R. Li, T. M. Koh, W. L. Leong, S. Powar, A. Grimsdale, M. Grätzel, N. Mathews and S. G. Mhaisalkar, J. Mater. Chem. A, 2014, 2, 6305.

27 P. Ganesan, K. Fu, P. Gao, I. Raabe, K. Schenk, R. Scopelliti, J. S. Luo, L. H. Wong, M. Grätzel and M. K. Nazeeruddin, Energy Environ. Sci., 2015, 8, 1986.

28 S. M. Park, J. H. Heo, C. H. Cheon, H. Kim, S. H. Im and H. J. Son, J. Mater. Chem. A, 2015, 3, 24215.
29 M. Maciejczyk, A. Ivaturi and N. Robertson, J. Mater. Chem. A, 2016, 4, 4855.

30 T. Swetha and S. P. Singh, J. Mater. Chem. A, 2015, 3, 18329.

31 B. Xu, D. Q. Bi, Y. Hua, P. Liu, M. Cheng, M. Grätzel, L. Kloo,

A. Hagfeldt and L. C. Sun, Energy Environ. Sci., 2016, 9, 873.

32 J. Wang, Y. Chen, F. S. Li, X. P. Zong, J. L. Guo, Z. Sun and S. Xue, Electrochim. Acta, 2016, 210, 673.

33 J. Wang, Y. Chen, M. Liang, G. Y. Ge, R. J. Zhou, Z. Sun and S. Xue, Dyes Pigm., 2016, 125, 399.

34 S. Tang, Z. Y. Wang, B. Liu and C. E. Dong, Chin. Chem. Lett., 2015, 26, 744 .

35 R. H. Zheng, W. M. Wei, Y. Y. Jing, H. Liu and Q. Shi, J. Phys. Chem. C, 2013, 117, 11117.

36 G. X. Du, Y. S. Li, S. N. Ma, R. Wang, B. Li, F. J. Guo, W. L. Zhu and Y. M. Li, J. Nat. Prod., 2015, 78, 2968.

37 G. W. Wang, A. X. Zhou, S. X. Li and S. D. Yang, Org. Lett., 2014, 16, 3118.

38 G. W. Wang, A. X. Zhou, S. X. Li and S. D. Yang, Org. Lett., 2014, 16, 3118.

39 M. N. Grayson and J. M. Goodman, J. Am. Chem. Soc., 2013, 135, 6142.

40 Q. S. Hu, D. Vitharana, X. F. Zheng, C. Wu, C. M. S. Kwan and L. Pu, J. Org. Chem., 1996, 61, 8370.

41 Y. Imai, K. Kamon, T. Kinuta, N. Tajima, T. Sato, R. Kuroda and Y. Matsubara, Cryst. Growth Des., 2008, 8, 3493.

42 Y. Imai, K. Kamon, T. Kinuta, N. Tajima, T. Sato, R. Kuroda and Y. Matsubara, Cryst. Growth Des., 2009, 9, 4096.

43 S. S. Yu, W. Plunkett, M. Kim, E. Wu, M. Sabat and L. Pu, J. Org. Chem., 2013, 78, 12671.

44 F. J. Miao, J. Zhou, D. M. Tian and H. B. Li, Org. Lett., 2012, 14, 3572 .

45 S. S. Yu, A. M. DeBerardinis, M. Turlington and L. Pu, J. Org. Chem., 2011, 76, 2814.

46 X. P. Zong, Z. Sun, H. Wang, J. Wang, M. Liang and S. Xue, Chem. Commun., 2015, 51, 14076.

47 M. S. Kang, S. D. Sung, I. T. Choi, H. Kim, M. Hong, J. Kim, W. I. Lee and H. K. Kim, ACS Appl. Mater. Interfaces, 2015, 7, 22213.

48 P. R. F. Barnes, K. Miettunen, X. Li, A. Y. Anderson, T. Bessho, M. Grätzel and B. C. O'Regan, Adv. Mater., 2013, 25, 1881.

49 H. Choi, S. Park and S. Paek, J. Mater. Chem. A, 2014, 2, 19136.

50 Y. K. Song, S. T. Lv, X. C. Liu, X. G. Li, S. R. Wang, H. Y. Wei, D. Li, Y. Xiao and Q. Meng, Chem. Commun., 2014, 50, 15239.

51 G. D. Niu, W. Z. Li, F. Q. Meng, L. D. Wang, H. P. Dong and Y. Qiu, J. Mater. Chem. A, 2014, 2, 705.

52 Z. S. Huang, H. L. Feng, X. F. Zang, Z. Iqbal, H. P. Zeng, D. B. Kuang, L. Y. Wang, H. Meierd and D. R. Cao, J. Mater. Chem. A, 2014, 2, 15365.

53 H. S. Kim, C. R. Lee, J. H. Im, K. B. Lee, T. Moehl, A. Marchioro, S. J. Moon, R. Humphry-Baker, J. H. Yum, J. E. Moser, M. Grätzel and N. G. Park, Sci. Rep., 2012, 2, 00591.

54 F. G. Zhang, X. C. Yang, H. X. Wang, M. Cheng, J. H. Zhao and L. C. Sun, ACS Appl. Mater. Interfaces, 2014, 6, 16140. 
55 Z. L. Ku, Y. G. Rong, M. Xu, T. F. Liu and H. W. Han, Sci. Rep., 2013, 3, 3132.

56 H. Wang, A. D. Sheikh, Q. Y. Feng, F. Li, Y. Chen, W. L. Yu, E. Alarousu, C. Ma, M. A. Haque, D. Shi, Z. S. Wang, O. F. Mohammed, O. M. Bakr and T. Wu, ACS Photonics, 2015, 2, 849.

57 S. Park, J. H. Heo, J. H. Yun, T. S. Jung, K. Kwak, M. J. Ko, C. H. Cheon, J. Y. Kim, S. H. Im and H. J. Son, Chem. Sci., 2016, 7, 5517.
58 J. Huang, M. Wang, L. Ding, J. Deng and X. Yao, Semicond. Sci. Technol., 2016, 31, 025009.

59 J. Huang, M. Wang, L. Ding, Z. Yang and K. Zhang, RSC Adv., 2016, 6, 55720.

60 N. Li, H. P. Dong, H. Dong, J. L. Li, W. Z. Li, G. D. Niu, X. D. Guo, Z. X. Wu and L. D. Wang, J. Mater. Chem. A, 2014, 2, 14973.

61 G. D. Niu, W. Z. Li, F. Q. Meng, L. D. Wang, H. P. Dong and Y. Qiu, J. Mater. Chem. A, 2014, 2, 705. 